\title{
Earnings Transparency, Cost of Debt and Cost of Equity: A Cross-Country Examination
}

\author{
Eduardo Flores ${ }^{1}$, Joelson Oliveira Sampaio ${ }^{2}$, Aziz Xavier Beiruth ${ }^{3}, \&$ Aldy Fernandes da Silva ${ }^{4}$ \\ ${ }^{1}$ Department of Accounting \& Actuarial Science, University of São Paulo - Brazil \\ ${ }^{2}$ São Paulo School of Economics (EESP) - Getulio Vargas Foundation (FGV), Brazil \\ ${ }^{3}$ Fucape Business School - Vitória - Brazil \\ ${ }^{4}$ Fecap Business School - São Paulo - Brazil \\ Correspondence: Eduardo Flores, Department of Accounting \& Actuarial Science, University of São Paulo - \\ Brazil
}

Received: June 1, 2020

Accepted: September 18, 2020

Online Published: September 23, 2020

doi:10.5539/ibr.v13n10p115

URL: https://doi.org/10.5539/ibr.v13n10p115

\begin{abstract}
This study evaluates the effect of earnings transparency on the cost of debt (Ki) and cost of equity (Ke). Previous literature has demonstrated that earnings transparency can reduce the Ke, especially in very well-developed stock markets. However, our main hypothesis is that this finding does not necessarily remain the same when considering the Ki. More specifically, this is because investors and creditors have different interests, concerns, and views about financial statements and accounting procedures. Using two proxies of earnings transparency, our findings support this conjecture, indicating that while an increase in earnings transparency reduces the Ke, this relationship does not keep that same impact on Ki. This study has implications for standard setters, debt holders and companies regarding the changes stemming from IFRS convergence, contributing to the prior literature which indicate that creditors and investors need different kind of information due to the distinct decision-making process.
\end{abstract}

Keywords: accruals, cost of debt, cost of equity, earnings transparency, timeliness, IFRS

\section{Introduction}

The International Accounting Standards Board (IASB) states that the purpose of financial reporting is to provide information to investors, lenders and other creditors to assist them in making resources decisions (IASB, $2013 \mathrm{pp}$. 22). Despite the general purpose established by the IASB, one must determine whether those stakeholders are concerned with various issues surrounding company performance. Bodie et al. (2011) argued that while investors are looking and waiting for earnings, cash flow and dividends, creditors and lenders, for their part, are assessing cash flows and guarantees to ensure timely interest payments and the repayment of the principal to the holders of a debt security.

Following these arguments, it is conceivable that different types of stakeholders can variously perceive the quality of financial statements. Earnings transparency is one topic that has been linked to the quality of accounting information, which reduces the cost of capital and more specifically the cost of equity (e.g., Francis et al., 2005; Barth et al., 2013; Beigi et al., 2016). However, there is less evidence that this possible feature produces the same impact on the cost of debt, since cost of debt studies are rare compared to those on earnings transparency and cost of capital.

Ball et al. (2015) investigated the mismatch between investors' and creditors' perspectives regarding the use of financial statements through the IFRS adoption in some countries. They found a significant reduction in the use of balance sheet covenants for lenders, indicating that some accounting concepts are not equally seen as an increment in financial reporting usefulness for both groups, such as fair value measurement, for instance. They argued that the effect in debt covenants is ambiguous when financial transparency is the focus, which leads us to analyze the relevance to debt holders.

Similarly, Demerjian (2011) confirmed that in the United States, a country where the IFRS is not allowed for local companies, there was a reduction of approximately $50 \%$ in the use of such indicators based on equity 
balance sheet numbers in the period from 1996 to 2007. Demerjian (2011) stated that lenders focus on borrower ability to generate cash, which reduces the focus on earnings transparency.

The results presented by Ball et al. (2015) and Demerjian (2011) might be better understood as a reaction from creditors to the use of more discretionary accounting policies. Likewise, the aversion presented by this group of users in the financial statements is reflected in the reduction of employment accounting numbers as a reference for verifying the fulfillment of contractual relations between the companies and their stakeholders.

We predict that earnings transparency impacts cost of equity, although this is not as important for cost of debt. Our prediction is based on Kothari (2000), Ball et al. (2015), Demerjian (2011) and Barth et al. (2013). Kothari (2000)'s findings indicated that earnings transparency is important for firms in reducing their cost of capital, but there is less discussion about the cost of debt.

Barth et al. (2013) argued that accounting standards could result in a variation in the explanatory power of the return-to-earnings ratio that may be reflected in a change of profit transparency and in the variation in companies' fundamentals, such as the cost of capital. Hung and Qiao (2017) found a positive relation between crash risk and earnings transparency, which the authors call a potential 'dark side' of explanatory earnings in stock markets. Kothari (2000) believed that regulators and investors demand high-quality financial reporting because it directly affects financial markets.

Beigi et al. (2016) stated that earnings transparency is generated by information that is accessible, relevant, reliable, comprehensive and timely for accounting users. From this conjecture, earnings transparency could be seen as a derivation of timeliness and conservatism properties (Ball et al., 1999).

The profit resulting from a variation cannot be explained in the profit-and-return relationship, as reflected in the variation in profits and in the variations of the company's fundamentals.

Nevertheless, considering the previous arguments, which state that creditors and lenders are more interested in cash flows and real guarantees, there is no logical and empirical evidence that earnings transparency has the same power to reduce the cost of debt, such as on the cost of equity statistically. Therefore, our main research question is as follows: Does earnings transparency have the same relevance for the cost of debt (Ki) and the cost of equity (Ke)?

According to Barth et al. (2013), if financial statements are more transparent, then uncertainty regarding the value of their equity will potentially be lower, and therefore firms will enjoy a minor cost of capital increasing their value. For these reasons, reducing the cost of capital is a crucial issue for an enterprise's success. Francis $e t$ al. (2005), for their part, established that lack of earnings transparency raises information risks. As a result, investors will demand a higher return on investments and, consequently, the cost of shares will increase.

To answer this question, we gathered sample data comprising 6,725 firm-observations collected in 32 countries in America and Europe, which were combined into six regions and that all countries adopted IFRSs. Details about sample-data filters are presented in Section 3 - Methodological approach. Using this archive, we calculated the earnings transparency measure following the approach suggested by Barth et al. (2013), referred to as TRANS below.

Our results indicated that while earnings transparency significantly negatively and statistically affects the cost of equity (Ke), in all regions characterized by subsamples, there was no indication that this feature of accounting information is an issue for the cost of debt (Ki). These results can be explained by (i) an accounting procedure, such as fair value measurement, which is one of the main attributes of IFRS, for instance and that potentially provides an increase in earnings transparency but is not necessarily equally perceived by creditors, such as investors, and consequently does not affect lenders' judgment of the agreed interest rates in financial liabilities contracts; and (ii) creditors may not be able to understand and incorporate the specifications of accounting information quality in their credit risk models.

The main contribution of this study to the literature is based on the difference conceptualization and relevance of accounting information for several groups such as investors and creditors. Investors comprise heterogeneous individuals who interact in distinct ways with public and private companies. Creditors, lenders, and others financial resources allocators, as well as investors, also comprise several categories. Hence, one cannot expect accounting information to also be useful for both groups, as these stakeholders differ in terms of origins and concerns. For this reason, we believe it is important to bring this discussion to the fore because several jurisdictions, such as Latin America's emerging economies, have prevalent financial markets but not necessary capital markets. Thus, it is important to understand creditors' views on financial statements and accounting treatments and to pay attention to those who use these financial statements, which aim to provide information that will affect their decisions. 
The remainder of this paper is organized as follows. The next section introduces the relevant literature on earnings transparency and how this feature of accounting information is still related to the cost of debt and equity; in this section we also develop our hypotheses. Section 3 provides the methodological details on econometric specifications and the composition of the sample data. Section 4 presents the descriptive statistics and the results found. Section 5 concludes our analysis and indicates potential avenues for future studies.

\section{Literature Review and Hypotheses Development}

This section reviews the most relevant literature on earnings transparency. It also develops our hypotheses about the association between the cost of equity and earnings transparency, with some background about the cost of debt.

\section{Earnings transparency}

According to Barth and Schipper (2008), earnings transparency can be defined as a magnitude to which financial statements disclose a firm's core economics in an approach that is readily comprehensible by those using these reports. It is very relevant to mention that the expression Financial Reporting Transparency is used more comprehensively than earnings transparency. Bushman et al. (2004), for their part, argued that transparency in accounting information refers to the pervasive disposal of relevant, trustworthy information about the timeliness of performance, financial situation, and investment opportunities, among other issues. In short, from a theoretical point of view, earnings transparency can be seen as a specific feature of accounting reporting quality.

Several studies have related the advantages of better disclosures and have thus shown that some progress is being made in financial reporting transparency. Kim and Verrecchia (1994) verified that increased transparency can successfully reduce information asymmetries and improve the liquidity of a company's stock. Healy et al. (1999) confirmed that transparency is positively associated with share prices returns. Other authors (e.g., Kumari and Mishra, 2018; Diamond and Verrecchia, 1991; Lang et al., 2012) have confirmed that transparency increases stock liquidity, reducing the cost of capital and increasing a company's valuation.

Gaumer et al. (2009) suggested that high-quality earnings accurately reflect both a company's current and past operating performance and that these gains are an indication of future operating performance and are reliable valuation measures for the company, and that these are sustained by strong cash flows, contain low levels of accruals and profit margins, and indicate robust asset turnover. These factors are crucial to investment decisions and company value.

According to Barth et al. (2013, pp. 209), one should '[...] operationalize earnings transparency by developing a measure based on the explanatory power of the returns-earnings relation, i.e., the extent to which earnings and change in earnings covary contemporaneously with stock returns.' This statement is not necessarily a new concept in market-based accounting research. Easton and Harris (1991) and Bushman et al. (2004) are examples of previous studies taking into consideration that earnings transparency is the relation between earnings and change in earnings and contemporaneous stock returns.

The earnings transparency measure (TRANS) designed by Barth et al. (2013) takes into consideration a two-step estimation procedure developed to capture an intertemporal and cross-sectional effect on accounting information quality. Basically, TRANS is a sum of $\mathrm{R}^{2}$ as seen below in Equation (1) for the firm $i$ in year $t$ :

$$
\operatorname{TRANS}_{i, t} \equiv \operatorname{TRANSI}_{j, t}+\operatorname{TRANSIN}_{p, t}
$$

where TRANSI is the annual returns-earnings relations estimated by industry $\mathrm{j}$ in year $\mathrm{t}$. According to the authors, 'There is a strong industry component to the returns-earnings relation as a result of accounting practices likely being similar within industries' (Barth et al., 2013, pp. 210). This element might be understood as the effect of earnings transparency on stock returns in a cross-sectional timing perspective, and it is calculated according to Equation (2) as follows:

$$
R E T_{i, j, t}=\alpha_{0}^{I}+\frac{\alpha_{1}^{I} E_{i, j, t}}{P_{i, j, t-1}}+\frac{\alpha_{2}^{I} \Delta E_{i, j, t}}{P_{i, j, t-1}}+\varepsilon_{i, j, t}=\operatorname{TRANSI}
$$

According to the original calculation provided by Barth et al. (2013), RET is the annual return measured beginning three months after the firm's fiscal year end, $E_{t} / P_{t-1}$ is earnings before extraordinary items and discontinued operations deflated by beginning of year price, and $\Delta E$ is changes in earnings from year $t-l$ to year $t$.

The second term, TRANSIN, is the annual returns-earnings relation estimated by the portfolio based on the residuals from the industry regressions (Equation (3)). In general terms, this item is calculated to express the 
longitudinal effect of earnings quality on stock returns, as expressed in Equation (3):

$$
R E T_{i, p, t}=\alpha_{0}^{I}+\frac{\alpha_{1}^{I} E_{i, p, t}}{P_{i, p, t-1}}+\frac{\alpha_{2}^{I} \Delta E_{i, p, t}}{P_{i, p, t-1}}+\varepsilon_{i, p, t}=\operatorname{TRANSIN}
$$

Barth et al. (2013) highlighted that to estimate Equation (3), it is necessary to replace observations from each industry-year regression, obtained in Equation (2), into one of four portfolios $(p)$ based on a number of their association residuals from each annual regression for that industry.

It is especially important to mention that investors can obtain information about modifications in a firm's value from earnings or other sources and that TRANS reflects only the extent to which earnings and change in earnings, and data associated with earnings and change in earnings, explain returns.

\section{Earnings transparency and cost of debt}

Straight debt is a relevant funding source for companies. For this reason, indebtedness has been studied for more than five decades as a device for optimizing companies' value (e.g., Modigliani and Miller, 1958). Several researchers have dedicated efforts to better understanding how debt bonds can be used to improve firms' returns.

Kraus and Litzenberger (1973) formulated the classical version of the trade-off theory, which considers that organizations seek a balance between their own and third-party capital, and in this way generate a cost-benefit relationship acceptable to the company. In addition, the authors pointed out that the fiscal and financial expenses aspects affect corporate decisions in terms of obtaining values. According to Lee and Gentry (1995, pp. 397), 'for financial managers, the pecking hypothesis implies that domestic financing is preferable to external financing. When external financing is inevitable, direct debt is preferable to convertible bonds, and the latter are preferable to ordinary shares.'

According to Uyemura and Van Deventer (1993), the interest rate is the main component of a debt's cost. In a fundraising situation, the interest rate comes from the creditors' and lenders' assessment, taking into account the relationship between credit risk and the returns expectation (Duffie and Singleton, 2012). Gerlach and Assenmacher (2008) explained that interest rate is formed by the term structure of interest (TSI), also known as the yield curve, which takes into consideration macroeconomic factors such as currency depreciation, exchange parity for foreign investors, fiscal policies, and others, as well as microeconomic factors such as debtors' industry, cash-flow and credit risk, for instance.

Some decades ago, several approaches were developed to model credit risk and come up with an interest rate that produces a balance between risks and returns trade-off; examples of these techniques include the five C's of credit, the rating model, credit scoring, and pricing modeling due to credit risk (Chaia, 2003).

Despite these developments in credit risk measurement, there has been little research relating accounting information quality with cost of debt. Only a few studies have examined this question, e.g., Sengupta (1998), Mazumdar and Sengupta (2005), Francis et al. (2005), and Shi and Zhang (2007). However, there is no consensus about the effect of accounting information on lenders, and these studies seemingly did not consider that to calculate an interest rate, creditors take into consideration more than the public information available about the companies. Universal banks, for instance, aiming to reduce informational asymmetry, request private data from borrowers and, in some situations, banks provide funds for their clients due to the real guarantees offered. Calcagnini et al. (2014, pp. 3) argued that 'economists' instinct and conventional wisdom in the banking community would support the idea that secured loans are less risky and, therefore, should carry lower interest rates.'

In this context, the main criterion used to reduce interest rates is the cost of debt, and it is not the quality of accounting information but the real guarantees provided that mitigate the credit risk and, consequently, improve the repayments of interest and of the principal amount. These arguments allow us to weight those investors and creditors with different informational needs. While investors are concerned with incomes, which are used to calculate dividends to be paid, according to Ball et al. (2015), stakeholders will not necessarily understand accounting features in the same way. Notwithstanding, although earnings transparency reduces informational asymmetry between creditors and borrowers, it is not enough to affect a significant reduction in interest rates. Therefore, we formulate Hypothesis (1) as follows:

\section{H1: There is no statistical relationship between earnings transparency and cost of debt.}

\section{Earnings transparency and cost of equity}

The quality of accounting information is essential to investors, who must use these data to make decisions about a company's value. Healy and Palepu (2001) pointed out that the demand for transparent financial statements arises from the need to reduce information asymmetry and agency conflicts between managers and external 
investors and that the credibility of financial statement disclosures should be reinforced by regulators, auditors and other capital market intermediaries.

Using a model consistent with the capital asset pricing model (CAPM), Lambert et al. (2007) examined how financial statement disclosures affect the cost of capital in the presence of asset diversification and demonstrated that the quality of accounting information has a direct effect on the evaluation of cash flows, suggesting that the quality of profits may affect the cost of capital (Johnstone, 2015). This finding indicates that earnings transparency decreases the cost of equity-decreasing beta's variance. Francis et al. (2008) found that firms with higher earnings transparency have more voluntary disclosures than firms with lower earnings transparency. They also verified that more voluntary disclosure is associated with a lower cost of capital and demonstrate the importance of viewing voluntary disclosure as a response to earnings transparency when analyzing the cost of capital consequences of such disclosures.

Bhattacharya et al. (2013) revealed an association between lower earnings transparency and higher information asymmetry, showing that low earnings quality exacerbates information asymmetry during the earnings announcements period.

Barth et al. (2015) concluded that uncertainty at earnings announcements and higher asymmetric timeliness are associated. This study indicates that the more asymmetric the earnings, the slower the resolution of equity investor disagreement, which is a problem for equity holders.

These are only a few examples of how earnings transparency has been researched and correlated with cost of capital, more specifically cost of equity. The main idea behind these studies is that investors are exposed to the risk-return relation. Hence, they must forecast earnings, cash flow, and dividends to discount it at a rate which represents the trade-off to make or forego an investment. Thus, it is possible to establish that a stock price is determined by the sum of several dividends discounted by a rate (Penman, 2013).

These projections are created using historical value-added forecast information. For example, if an analyst must estimate EBITDA, he will begin by calculating this term, using financial statements from the last years and compute the mean value. Then, using estimated information, i.e., inflation rate, currency, prices and others, it will be possible to complete the assessment. Thus, higher earnings transparency increases the quality of financial reporting, allowing investors to obtain forecasts that are more reliable and that reduce informational asymmetry, thus impacting the cost of equity. Therefore, we formulate Hypothesis (2) as follows:

H2: There is a negative and statistical relationship between earnings transparency and cost of equity.

Research design

This section presents the most relevant details regarding the methodological procedures related to sample selection, descriptive statistics, and econometric specifications.

\section{Statistical models and variables}

To test these hypotheses, we considered two statistical models. First, we constructed Equation (4) aiming to test Hypothesis (1), as follows:

$$
\begin{gathered}
K i_{i, t}= \\
\alpha+\beta_{1} \operatorname{TRANS}_{i, t}+\beta_{2} L E V_{i, t}+\beta_{3} \operatorname{SIZE}_{i, t}+\beta_{4} R O A_{i, t}+\beta_{5} M T B_{i, t}+ \\
\sum_{j=1}^{24} \beta_{j} \text { Industry }+\sum_{k=1}^{34} \beta_{k} \text { Country }+\omega_{i, t}
\end{gathered}
$$

where $\mathrm{Ke}$ is the cost of equity of firm $i$ in year $t$; TRANS is the earnings transparency measure of firm $i$ in year $t$ and denotes the interest variable of this evaluation, $L E V$ is the financial leverage of firm $i$ in year $t$, and SIZE is the magnitude of firm $i$ in year $t$.

Equation (5) was used to test the Hypothesis (2); the only difference between this model and the first one is the subject term, as follows:

$$
\begin{gathered}
K e_{i, t}= \\
\alpha+\beta_{1} \operatorname{TRANS}_{i, t}+\beta_{2} L E V_{i, t}+\beta_{3} S I Z E_{i, t}+\beta_{4} R O A_{i, t}+\beta_{5} M T B_{i, t}+
\end{gathered}
$$




$$
\sum_{j=1}^{24} \beta_{j} \text { Industry }+\sum_{k=1}^{34} \beta_{k} \text { Country }+\omega_{i, t}
$$

where $\mathrm{Ki}$ is the cost of debt of firm $i$ in year $t$. TRANS is the earnings transparency measure of firm $i$ in year $t$ and denotes the interest variable of this evaluation; and $L E V, S I Z E, R O A, M T B$, Sector, and Country are control variables used to moderate sample dispersion. Their description and operationalization, such as dependents and interest variables, are provided in Table 1.

Table 1. Variables

\begin{tabular}{|c|c|c|c|}
\hline Variable & Label & Description & Preview Literature \\
\hline DAC & Discretionary Accruals & $\begin{array}{l}\text { Obtained using Modified Jones } \\
\text { Model (1995). }\end{array}$ & $\begin{array}{l}\text { Dechow et al. (1995), Subramanyam (1996), } \\
\text { McNichols (2000), Leone et al. (2005), Ali } \\
\text { et al. (2011). }\end{array}$ \\
\hline Ke & Cost of Capital & $\begin{array}{l}\text { Variable computed using the Fama } \\
\& \text { French Three-Factor Model. }\end{array}$ & $\begin{array}{l}\text { Gebhardt et al. (2001), Thomas et al. (2001), } \\
\text { Ohlson and Juettner-Narouth (2005), Hou et } \\
\text { al. (2012). }\end{array}$ \\
\hline $\mathbf{K i}$ & Cost of Interest & $\begin{array}{l}\text { Cost of debt considering market } \\
\text { value as reference. }\end{array}$ & $\begin{array}{l}\text { Sweeney (1994), Dechow and Skinner } \\
\text { (2000), Dichev and Skinner (2002), } \\
\text { Charitou } \text { et al. (2007), Jelinek (2007). }\end{array}$ \\
\hline$L E V$ & Financial leverage & $\begin{array}{c}\text { The ratio of loans and financing } \\
\text { over total assets. }\end{array}$ & $\begin{array}{l}\text { Dechow et al. (1995), McNichols (2000), } \\
\text { Larcker and Richardson (2004), Kothari et } \\
\text { al. (2005), Othman and Zeghal (2006) }\end{array}$ \\
\hline$M T B$ & Market to Book & $\begin{array}{c}\text { Market Capitalization over Equity } \\
\text { Value. }\end{array}$ & \\
\hline$R O A$ & Return on Assets & $\begin{array}{c}\text { Net income of } t \text { over total assets of } \\
t-1 .\end{array}$ & Barth et al. (2013), \\
\hline $\begin{array}{l}\text { SIZE } \\
\text { TRANS }\end{array}$ & $\begin{array}{l}\text { Size of firm } \\
\text { Earnings transparency }\end{array}$ & $\begin{array}{l}\text { Natural logarithm of total assets. } \\
\text { The sum of TRANSI and } \\
\text { TRANSIN. }\end{array}$ & Beigi et al. (2016). \\
\hline TRANSI & $\begin{array}{l}\text { Cross-section measure } \\
\text { of earnings } \\
\text { transparency }\end{array}$ & $\begin{array}{l}\text { Measure of earnings transparency } \\
\text { considering returns from current } \\
\text { year. }\end{array}$ & \\
\hline TRANSIN & $\begin{array}{l}\text { Intertemporal measure } \\
\text { of earnings } \\
\text { transparency }\end{array}$ & $\begin{array}{l}\text { Measure of earnings transparency } \\
\text { considering returns from a } \\
\text { time-series. }\end{array}$ & \\
\hline
\end{tabular}

Equations (4) and (5) were adjusted using panel data methodology, in accordance with Wooldridge (2009) and Othman and Zeghal (2006). Given that the results of Hausman's test models' coefficients were obtained through fixed-effects estimation, due to potential intrinsic heteroscedasticity, the estimated parameters from both equations were obtained through the generalized linear models following Hardin and Hilbe (2012).

\section{Sample and descriptive statistics}

This research is an applied study developed using an archival methodology. The sample data were built using Thomson Reuters Eikon ${ }^{\circledR}$ and comprised thirty-four different capital markets displayed in six different microregions in the Americas and Europe. Firm-observations were collected from 2010 to 2016. We excluded from the sample all observations with missing values. To mitigate the effects of the outliers in the sample, the database variables were winsorized using the 0.5 and 99.5 percentiles. The final sample comprised 6,725 company-year observations for 1,050 companies and reflected the largest publicly traded companies in Latin America, North America, and Europe.

Table 2 shows the descriptive statistics for all variables. Panel A is based on all countries, industries and longitudinal series, indicating that $\mathrm{Ki}$ has a larger standard deviation compared to Ke: 0.96 against 0.07 , respectively. This result can be interpreted as an indication of homogeneity among firms comprising the sample. Additionally, there is a natural expectation that $\mathrm{Ki}$ has a more pronounced variance than Ke because credit markets are intuitively less standardized than capital markets. Panel B, which provides descriptive statistics based on regions, corroborates this statement. The standard deviation for variable Ki goes from 0.13 in North America to 1.69 in Northern Europe. Based on Panel B, it is possible to observe a concentration approximately 0.05 for the Ke term. Panel $\mathrm{C}$ shows the mean and standard deviation, both based on industries. Taking dependent variables as a reference, it is possible to predicate the existence of a strong variation between economic sectors going from 0.05 to 0.09 in the Ke variable and from 0.05 to 0.31 based on Ki.

Panel D shows the correlations for all variables calculated using Pearson's and Spearman's methodology. The results indicate that Ke and TRANS are negatively correlated under Spearman's approach (-0.020**), and this is significant at five percent. Another interesting correlation is between Ke and financial leverage ( $L E V)$ : these 
terms are positively correlated at 5 percent. Although Ki is negatively associated with TRANS, there is no statistical significance in this relation. Another significant finding provided by Table 2, once again on the verification of the correlations between control variables and the subject terms $L E V, M T B, R O A$, and SIZE, showed statistical significance with both subject terms Ke and Ki.

The cost of Equity is negatively correlated with TRANSI, according to Spearman's indicator, and it is positively associated with TRANSIN. The cost of Debt has negative correlations with TRANSI and TRANSIN, following Pearson's and Spearman's parameters. However, these values are not significant.

Table 2. Descriptive Statistics

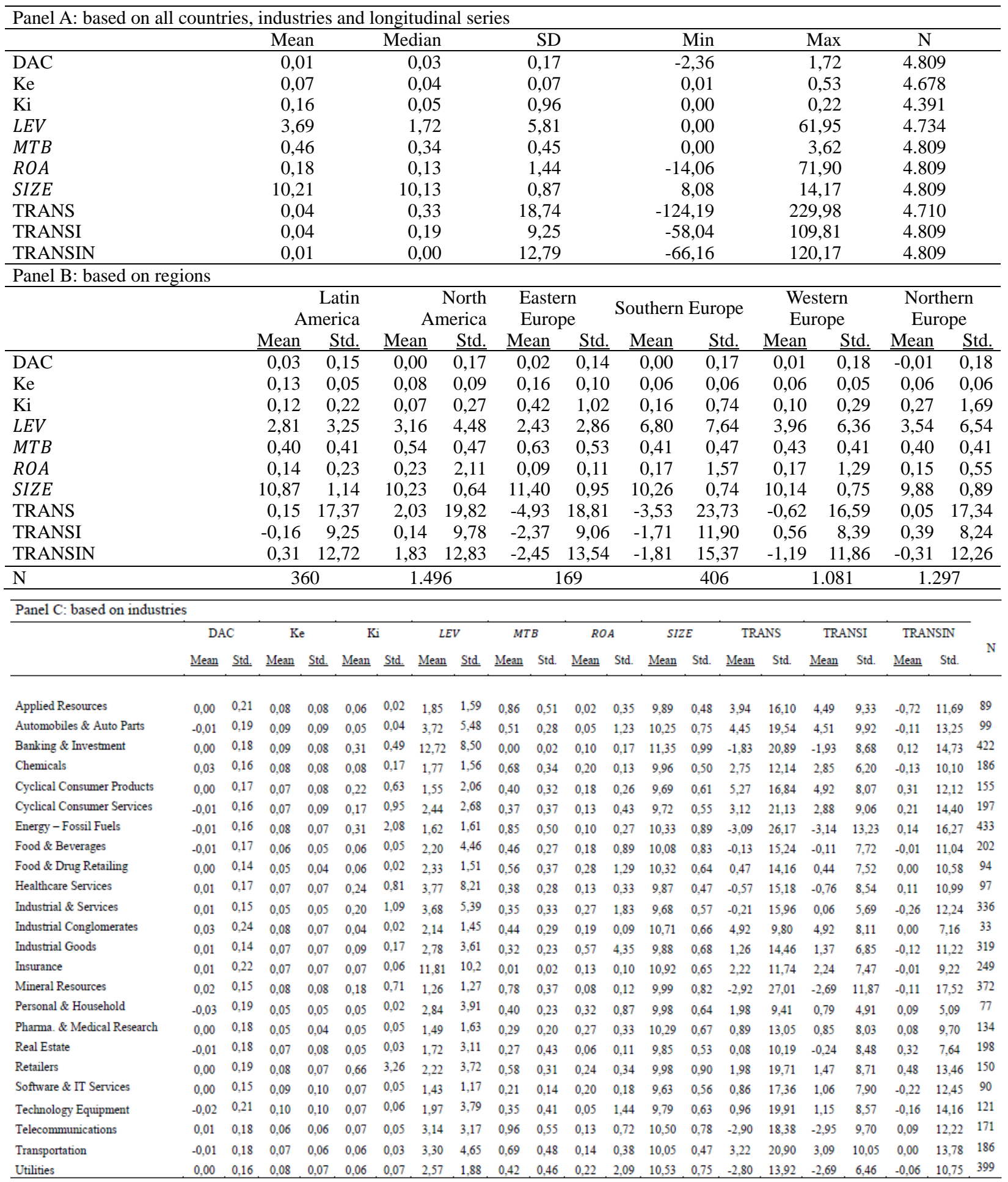

Panel D: Pearson and Spearman correlation matrices 


\begin{tabular}{|c|c|c|c|c|c|c|c|c|c|c|c|}
\hline & & 1 & 2 & 3 & 4 & 5 & 6 & 7 & 8 & 9 & 10 \\
\hline 1 & DAC & - & 0.018 & $0.023 * *$ & -0.002 & $0.026^{*}$ & -0.011 & 0.019 & 0.009 & 0.001 & 0.003 \\
\hline 2 & $\mathrm{KE}$ & 0.019 & - & $0.075 * *$ & -0.022 & $0.024 *$ & $\begin{array}{r}-0.082 \\
*\end{array}$ & $0.116^{*}$ & -0.000 & -0.010 & 0.007 \\
\hline 3 & $\mathrm{KI}$ & $\begin{array}{r}-0.00 \\
5\end{array}$ & -0.013 & - & $0.079 *$ & $\begin{array}{r}-0.127 \\
*\end{array}$ & $\begin{array}{r}-0.027 \\
*\end{array}$ & $-0.037 *$ & -0.013 & $-0.024 *$ & -0.004 \\
\hline 4 & LEV & 0.002 & 0.009 & 0.002 & - & $\begin{array}{r}-0.289 \\
*\end{array}$ & $0.076^{*}$ & $0.368^{*}$ & $0.026 * *$ & -0.006 & 0.022 \\
\hline 5 & MTB & 0.021 & $0.038 * *$ & $\begin{array}{r}-0.046^{*} \\
*\end{array}$ & $\begin{array}{r}-0.257 \\
*\end{array}$ & - & $0.040^{*}$ & $-0.188 * *$ & $\begin{array}{r}-0.067 * * \\
*\end{array}$ & $-0.037 *$ & $-0.035^{*}$ \\
\hline 6 & ROA & $\begin{array}{r}-0.00 \\
0\end{array}$ & -0.014 & -0.004 & $0.162 *$ & 0.003 & - & $\begin{array}{r}-0.121 * * \\
*\end{array}$ & $0.108 * *$ & $0.098 *$ & $0.068 *$ \\
\hline 7 & SIZE & 0.017 & $\begin{array}{r}0.148 * * \\
*\end{array}$ & $-0.038^{*}$ & $0.370^{*}$ & $\begin{array}{r}-0.149 \\
*\end{array}$ & -0.017 & - & 0.011 & $-0.027 *$ & $0.035^{* *}$ \\
\hline 8 & Trans & $\begin{array}{r}-0.00 \\
9\end{array}$ & $-0.030 *$ & -0.019 & -0.018 & $\begin{array}{r}-0.041 \\
*\end{array}$ & 0.005 & 0.005 & - & $0.583 *$ & $0.796^{*}$ \\
\hline 9 & Transi & $\begin{array}{r}-0.00 \\
6\end{array}$ & -0.012 & 0.001 & -0.020 & $\begin{array}{r}-0.052 \\
*\end{array}$ & 0.009 & -0.022 & $0.773 * * *$ & - & $\begin{array}{r}0.057 * * \\
*\end{array}$ \\
\hline $\begin{array}{l}1 \\
0\end{array}$ & $\begin{array}{l}\text { Transi } \\
\mathrm{n}\end{array}$ & $\begin{array}{r}-0.00 \\
9\end{array}$ & $-0.034 * *$ & $-0.028 *$ & -0.012 & -0.021 & 0.000 & $0.023 *$ & $0.888 * * *$ & $\begin{array}{r}0.394 * * \\
*\end{array}$ & \\
\hline
\end{tabular}

Note: $* * *$ indicates that the correlation is significant at the 0.01 level; ** shows that the correlation is significant at the 0.05 level; and $*$ shows that the correlation is significant at the 0.10 level.

Regarding the variable TRANS, the descriptive statistics denote that the mean of this term in a general context, Panel A, is 0.33, with a strong standard deviation equal to 18.74. Panel B shows that companies located in Eastern Europe have the highest scores of TRANS (2.45), while firms in Latin America and Northern Europe present lower values for this variable, 0.31. Based on Industries analysis, TRANS indicates a significant interval of means, beginning with 0.08 in real estate and ending with 5.27 in cyclical consumer products. This enormous gap shows how matter inserts itself in Equations (2) and (3), with country and sector as control variables aiming to reduce sample dispersion.

About TRANSI $^{1}$ and TRANSIN, ${ }^{2}$ Panel A shows that the first has a lower standard deviation compared with the second. However, TRANSI has the highest mean, 0.19, against 0.03 from TRANSIN. From a cross-regional perspective, both TRANSI and TRANSIN revealed a consistency across several countries.

\section{Results}

In this section, we present the findings of both hypotheses. First, we show the coefficients obtained for Hypothesis (1), and second, the results obtained for Hypothesis (2).

\section{Empirical findings for cost of debt and earnings transparency}

Given Table 3, we cannot reject the Hypothesis 1 - There is no relationship between earnings transparency and cost of debt. In all regions, the variable TRANS showed a negative association with the cost of debt; however, in no case was there statistical significance. The highest estimated coefficient was in Eastern Europe (-0.066), but it was without statistical significance even in very well-developed regions, like Northern-Europe.

\footnotetext{
1 TRANSI was computed considering $t$ from 2010 to 2016 and 24 industries.

2 TRANSIN was estimated by building four portfolios, as previously done by Barth et al. (2013).
} 
Table 3. Findings for Cost of Debt (KI) and Earnings Transparency

\begin{tabular}{|c|c|c|c|c|c|c|c|c|}
\hline VARIABLES & Prediction & $\begin{array}{c}\text { Overall } \\
\qquad \mathrm{Ki}\end{array}$ & $\begin{array}{c}\text { Latin } \\
\text { America } \\
\text { Ki }\end{array}$ & $\begin{array}{c}\text { North } \\
\text { America } \\
\text { Ki }\end{array}$ & $\begin{array}{c}\text { Eastern } \\
\text { Europe } \\
\mathrm{Ki}\end{array}$ & $\begin{array}{c}\text { Southern } \\
\text { Europe } \\
\text { Ki }\end{array}$ & $\begin{array}{c}\text { Western } \\
\text { Europe } \\
\mathrm{Ki}\end{array}$ & $\begin{array}{c}\text { Northern } \\
\text { Europe } \\
\mathrm{Ki}\end{array}$ \\
\hline TRANS & - & $\begin{array}{l}-0.0005 \\
(-0.40)\end{array}$ & $\begin{array}{l}-0.0003 \\
(-0.33)\end{array}$ & $\begin{array}{l}-0.0005 \\
(-0.94)\end{array}$ & $\begin{array}{l}-0.0066 \\
(-2.61)\end{array}$ & $\begin{array}{l}-0.0004 \\
(-0.56)\end{array}$ & $\begin{array}{l}-0.0010 \\
(-1.24)\end{array}$ & $\begin{array}{c}-0.0008 \\
(-0.19)\end{array}$ \\
\hline LEV & + & $\begin{array}{l}-0.0003 \\
(-0.21)\end{array}$ & $\begin{array}{c}0.0125^{* *} \\
(2.42)\end{array}$ & $\begin{array}{c}0.0000 \\
(0.02)\end{array}$ & $\begin{array}{c}0.2687 * * * \\
(4.35)\end{array}$ & $\begin{array}{l}-0.0012 \\
(-0.19)\end{array}$ & $\begin{array}{c}0.0008 \\
(0.29)\end{array}$ & $\begin{array}{l}0.0034 \\
(0.94)\end{array}$ \\
\hline SIZE & $?$ & $\begin{array}{c}-0.1078 * * * \\
(-4.69)\end{array}$ & $\begin{array}{l}-0.0352 \\
(-1.54)\end{array}$ & $\begin{array}{c}-0.0233^{*} \\
(-1.65)\end{array}$ & $\begin{array}{l}-0.1027 \\
(-1.39)\end{array}$ & $\begin{array}{c}-0.2011^{*} \\
(-1.70)\end{array}$ & $\begin{array}{c}-0.0413^{* *} \\
(-2.14)\end{array}$ & $\begin{array}{c}-0.2174 * * * \\
(-3.95)\end{array}$ \\
\hline$R O A$ & $?$ & $\begin{array}{l}-0.0421 \\
(-1.15)\end{array}$ & $\begin{array}{c}-0.0166 \\
(-0.33)\end{array}$ & $\begin{array}{l}0.0158 \\
(0.85)\end{array}$ & $\begin{array}{l}-0.3205 \\
(-0.60)\end{array}$ & $\begin{array}{c}0.0260 \\
(0.36)\end{array}$ & $\begin{array}{l}-0.0463 \\
(-0.92)\end{array}$ & $\begin{array}{l}-0.1300 \\
(-1.27)\end{array}$ \\
\hline MTB & $?$ & $\begin{array}{c}-0.1734 * * * \\
(-2.81)\end{array}$ & $\begin{array}{l}0.0198 \\
(1.24)\end{array}$ & $\begin{array}{c}-0.0234 \\
(-1.40)\end{array}$ & $\begin{array}{c}-0.5111^{*} \\
(-1.67)\end{array}$ & $\begin{array}{l}-0.1095 \\
(-1.09)\end{array}$ & $\begin{array}{c}-0.0354 * * \\
(-2.43)\end{array}$ & $\begin{array}{c}-0.4358^{* *} \\
(-2.18)\end{array}$ \\
\hline Fixed Event Industry & & Yes & Yes & Yes & Yes & Yes & Yes & Yes \\
\hline Fixed Event Country & & Yes & Yes & Yes & Yes & Yes & Yes & Yes \\
\hline Constant & & Yes & Yes & Yes & Yes & Yes & Yes & Yes \\
\hline $\mathrm{N}$ & & 4,187 & 271 & 1,298 & 158 & 334 & 983 & 1,143 \\
\hline Adj. R-squared & & 0.0277 & 0.1586 & 0.4863 & 0.1816 & 0.1196 & 0.0935 & 0.0253 \\
\hline
\end{tabular}

These findings could be indicating that creditors, debtholders, and lenders are potentially more interested in real guarantees, collateral guarantees, offered by borrowers than in the quality of accounting information as proxied by transparency (Ball et al., 2015). However, from the negative coefficient found in all regions, it might be understood that accounting information based on market returns has a very limited effect on interest rates, basically because debt holders are not necessarily concerned with firms' earnings, their returns are paid by companies presenting positive cash-flows, and their credit risk decreases because there are real guarantees for bonds and loans. These results differ from those of Sengupta (1998), Mazumdar and Sengupta (2005), Francis et al. (2005), and Shi and Zhang (2007). Most likely, these conflicting results arise from of fact that earlier researchers used only debt instruments negotiated in financial markets and excluded funding directly obtained in private negotiations. Bonds issued in publica markets can be considered stock market instruments, and not necessarily are evaluated by bondholders in the same way that financial institutions assess companies' figures in private deals. Thus, this implication is potentially more relevant for countries with a more developed credit market than capital markets, such as Brazil, for instance.

Demerjian (2011) and Ball et al. (2015) introduced the idea that investors and creditors perceive accounting information through different points. On the one hand, investors are more concerned with forecast figures; thus, if this information could be provided by companies at low or no cost, it would be a perfect scenario for them. On the other hand, debtholders are interested in decreasing credit risk and increasing returns; thus, if they require additional information, they will probably ask for additional collaterals that reduce risk-default, independent of earnings transparency and predictability, such as in private funding transactions.

The control variable $L E V$ denotes a negative signal in the overall subsample (-0.0003), even though we expected a positive signal due to the logical conjecture that leverage affects firms' risks assessment and, consequently, should impact the cost of debt. However, it is important to highlight that in the regional extracts, LEV shows a positive signal, except for Southern Europe, being statistically significant for Latin America $\left(0.0125^{* *}\right)$ and Eastern Europe $\left(0.2687^{* * *}\right)$, thereby corroborating the previous logical approach. These mixed results might be an indication that in regions with low interest rates, firms' leverage not necessary is so relevant to the cost of debt, potentially because it not increase the risk of bankruptcy like in countries with high rates of interest. 
One of the most relevant signals provided by the control variables comes from the SIZE. In overall composition and all subsamples, this variable presented a negative estimated parameter, being significant for the total sample $\left(-0.1078^{* * *}\right)$, North America $\left(-0.0233^{*}\right)$, Southern Europe $\left(-0.2011^{*}\right)$, Western Europe $\left(-0.0413^{* *}\right)$, and Northern Europe $(-0.2174 * * *)$. These findings indicate that firm size negatively affects the cost of debt. We use the natural logarithm of total assets as a proxy of SIZE; in this way, total assets can be considered as a real guarantee for debt investors, and it is more relevant to decrease interest rates than TRANS, which denotes earnings transparency.

It is important to mention that the verified $S I Z E$ and Ki relationship is expected, bearing in mind the theoretical development in this study; more specifically, we are arguing that debtholders decrease their interest rates through the real guarantees offered by companies, so a large number of assets can be proxied as the total of guarantees, and for this reason the negative and statistical signal between both.

The MTB variable reinforces these results, once showing a negative estimated coefficient for all the extracts, except for Latin America (0.0198). These negative coefficients were significant for the Overall $(-0.1734 * * *)$, Eastern Europe $\left(-0.5111^{*}\right)$, Western Europe $\left(-0.0354^{* *}\right)$, and Northern Europe $\left(-0.4358^{* *}\right)$ sets. MTB was computed as a ratio of the market capitalization over the equity value. According to Jones et al. (2007) and Othman and Zeghal (2006), it can be considered as a proxy of market expectation of companies' performance; thus, this variable still revealing that market expectation is also more relevant to decreasing the cost of debt than TRANS.

Although $R O A$ has shown itself to be an important control variable, given Panel D of Table 2 (Correlation Matrix), in the regressions presented in Table 3, ROA did not disclose matter effects on the cost of debt to the extent expected because debtholders are not refunded by earnings.

Furthermore, comparing the adjusted R-squared Table 3 shows the higher value in the North America (48.63\%), followed by Eastern Europe (18.16\%), Latin America (15.86\%), Southern Europe (11.96\%), Western Europe (9.35\%), Overall $(2.77 \%)$, and Northern Europe (2.53\%). All regressions were also controlled for industry effects, fixed event effects (timeliness), country controls, and the constant was inserted.

These findings reinforce the conceptual arguments that accounting information is not a prime criterion to reduce interest rates, most specifically because earnings transparency is not perceived by lenders as a relevant issue about financial statements. It is important to point out that under this view, creditors, potentially, are more concerned about the historical cash-flow to evaluate the payment ability of debtors.

Table 4 shows the results of the relationship between discretionary accruals and cost of debt. It was verified that DAC, denoting discretionary accruals obtained through MJM (1995), showed positive signals for all subsamples as well as in overall context; however, its statistical significance was not found in all columns.

Table 4. Findings for Cost of Debt (KI) and Discretionary Accruals

\begin{tabular}{|c|c|c|c|c|c|c|c|c|}
\hline & & Overall & $\begin{array}{c}\text { Latin } \\
\text { America }\end{array}$ & $\begin{array}{c}\text { North } \\
\text { America }\end{array}$ & $\begin{array}{c}\text { Eastern } \\
\text { Europe }\end{array}$ & $\begin{array}{l}\text { Southern } \\
\text { Europe }\end{array}$ & $\begin{array}{l}\text { Western } \\
\text { Europe }\end{array}$ & $\begin{array}{l}\text { Northern } \\
\text { Europe }\end{array}$ \\
\hline VARIABLES & Prediction & $\mathrm{Ki}$ & $\mathrm{Ki}$ & $\mathrm{Ki}$ & $\mathrm{Ki}$ & $\mathrm{Ki}$ & $\mathrm{Ki}$ & $\mathrm{Ki}$ \\
\hline DAC & + & $\begin{array}{c}0.0001 \\
(0.23)\end{array}$ & $\begin{array}{c}0.0002 \\
(1.43)\end{array}$ & $\begin{array}{c}0.0002 \\
(0.12)\end{array}$ & $\begin{array}{c}0.0001 \\
(1.32)\end{array}$ & $\begin{array}{c}0.0001 \\
(0.32)\end{array}$ & $\begin{array}{c}0.0000 \\
(0.02)\end{array}$ & $\begin{array}{c}0.0001 \\
(0.72)\end{array}$ \\
\hline$L E V$ & $?$ & $\begin{array}{c}0.0212 * * * \\
(2.85)\end{array}$ & $\begin{array}{c}0.0021 \\
(0.81)\end{array}$ & $\begin{array}{c}0.0141 * * \\
(0.34)\end{array}$ & $\begin{array}{c}0.0018^{*} \\
(1.74)\end{array}$ & $\begin{array}{c}-0.0007 \\
(-0.93)\end{array}$ & $\begin{array}{c}-0.0000 \\
(-0.03)\end{array}$ & $\begin{array}{c}-0.0000 \\
(-0.27)\end{array}$ \\
\hline SIZE & $?$ & $\begin{array}{c}-0.1211 * * \\
(-2.18)\end{array}$ & $\begin{array}{c}-0.0415 \\
(-0.53)\end{array}$ & $\begin{array}{c}-0.1584 \\
(-1.02)\end{array}$ & $\begin{array}{c}0.0032 \\
(0.18)\end{array}$ & $\begin{array}{c}0.0035 \\
(0.31)\end{array}$ & $\begin{array}{c}0.0033 \\
(0.52)\end{array}$ & $\begin{array}{l}0.0053 \\
(1.48)\end{array}$ \\
\hline$R O A$ & $?$ & $\begin{array}{c}0.0298 \\
(0.44)\end{array}$ & $\begin{array}{c}0.0003 \\
(0.01)\end{array}$ & $\begin{array}{c}-0.0400 \\
(-0.24)\end{array}$ & $\begin{array}{l}0.0215 \\
(0.90)\end{array}$ & $\begin{array}{c}0.0037 \\
(0.11)\end{array}$ & $\begin{array}{c}0.0075 \\
(0.70)\end{array}$ & $\begin{array}{l}0.0113 \\
(1.40)\end{array}$ \\
\hline MTB & $?$ & $\begin{array}{c}0.0174 \\
(1.16)\end{array}$ & $\begin{array}{c}-0.0023 \\
(-1.20)\end{array}$ & $\begin{array}{c}-0.3961 \\
(-1.24)\end{array}$ & $\begin{array}{c}-0.1095 \\
(-1.02)\end{array}$ & $\begin{array}{l}-0.0287 \\
(-2.24)\end{array}$ & $\begin{array}{c}-0.0358 \\
(-2.06)\end{array}$ & $\begin{array}{c}-0.1512 \\
(-2.51)\end{array}$ \\
\hline Fixed Event Industry & & Yes & Yes & Yes & Yes & Yes & Yes & Yes \\
\hline Fixed Event Country & & Yes & Yes & Yes & Yes & Yes & Yes & Yes \\
\hline Constant & & Yes & Yes & Yes & Yes & Yes & Yes & Yes \\
\hline $\begin{array}{l}\mathrm{N} \\
\text { Adj. R-squared }\end{array}$ & & $\begin{array}{c}352 \\
0.2952 \\
\end{array}$ & $\begin{array}{c}1,429 \\
0.0246 \\
\end{array}$ & $\begin{array}{c}165 \\
-0.0004 \\
\end{array}$ & $\begin{array}{c}390 \\
0.0384 \\
\end{array}$ & $\begin{array}{c}1,056 \\
0.0416 \\
\end{array}$ & $\begin{array}{c}1,216 \\
0.0054\end{array}$ & $\begin{array}{c}4,608 \\
0.0099 \\
\end{array}$ \\
\hline
\end{tabular}

These results show an additional perspective on the debt-holders' and creditors' concerns about companies' performance future. As prior mentioned, the relevance of accounting information differs between debt holders and investors; hence the discretionary component of earnings is not directly perceived by the cost of the debt 
compounding process. These results directly contradict those of Francis et al. (2005). Nonetheless, it is important to mention that we are using a cross-country database, while these researches focused on an individual jurisdiction.

It is also important to highlight that our results can also be interpreted that creditors consider accounting information in their decision-making process in a different way than do investors. Naturally, one financial institution may require financial statements from a potential client as well as explanations about some procedures and figures, especially because it is a private negotiation and firms are interested in raise funding from the financial industry; however, our results show that such earnings transparency and discretionary accruals are not enough to impact on the cost of debt.

These contextual findings, which still indicate that creditors do not necessarily pay attention to earnings quality and discretionary accruals, are in line with those of Myers (1977), Smith and Warner (1979) and Kothari et al. (2009), who revealed that debt market participants are more interested in verifying the liquidity of firms evaluating the credit risk. Thus, these authors offer a general explanation explaining that accounting information, in a scenario such as this one, plays a secondary role as an informative source. In such a context, if one company raise funding through debt instruments, which is an original financial liability and is a going concern, the debt market investors or bondholders are concerned with the effective credit risk that can be measured using several sources, such as rating agencies, macroeconomics indicators, industry level of activities or other informational providers different from financial statements, and its quality indicators, such as earnings quality and discretionary accruals.

According to Kothari et al. (2009), accounting information assumes a primary role in the debt market in ongoing concern situations or in a bankruptcy scenario; for this reason, it is necessary, in an event that affects a firm's liquidity, such as a financial crisis, to highlight the relevance of financial statements for debtholders.

\section{Empirical results for earnings transparency and cost of equity}

To teste H2: There is a negative and statistical relationship between earnings transparency and cost of equity, and provide an incremental robustness for our results, we also regressed the equations using the cost of capital $(\mathrm{Ke})$ as a dependent variable computed according to the Fama-French momentum approach. The primary aim of this procedure was motivated by the prior research of Barth et al. (2013), which allowed us to verify their findings from a cross-country perspective. 
Table 5. Robustness Test - Findings for Cost of Capital (KE) and Earnings Transparency

\begin{tabular}{|c|c|c|c|c|c|c|c|c|}
\hline \multicolumn{9}{|c|}{ Panel A: Cost of Equity (KE) and Earnings Transparency } \\
\hline \multirow[b]{2}{*}{ VARIABLES } & \multirow[b]{2}{*}{ Prediction } & \multirow{2}{*}{$\begin{array}{l}\text { Overall } \\
\text { Ke }\end{array}$} & \multirow{2}{*}{$\begin{array}{c}\text { Latin } \\
\text { America } \\
\mathrm{Ke}\end{array}$} & \multirow{2}{*}{$\begin{array}{c}\text { North } \\
\text { America } \\
\mathrm{Ke}\end{array}$} & \multirow{2}{*}{$\begin{array}{c}\text { Eastern } \\
\text { Europe } \\
\mathrm{Ke}\end{array}$} & \multirow{2}{*}{$\begin{array}{c}\text { Southern } \\
\text { Europe } \\
\mathrm{Ke}\end{array}$} & \multirow{2}{*}{$\begin{array}{c}\text { Western } \\
\text { Europe } \\
\mathrm{Ke}\end{array}$} & \multirow{2}{*}{$\begin{array}{c}\text { Northern Europe } \\
\mathrm{Ke}\end{array}$} \\
\hline & & & & & & & & \\
\hline \multirow[t]{2}{*}{ TRANS } & - & $-0.0013 * *$ & -0.0005 & $-0.0041 * * *$ & -0.0000 & $-0.0026 * * *$ & -0.0010 & -0.0001 \\
\hline & & $(-1.99)$ & $(-0.51)$ & $(-3.18)$ & $(-0.00)$ & $(-3.10)$ & $(-1.03)$ & $(-0.12)$ \\
\hline \multirow[t]{2}{*}{$L E V$} & + & $0.0045^{*}$ & 0.0040 & $0.0086 * *$ & $0.0813 * *$ & 0.0032 & $0.0092 * *$ & 0.0016 \\
\hline & & $(1.84)$ & $(0.55)$ & $(2.13)$ & $(2.50)$ & $(0.96)$ & $(2.20)$ & $(0.30)$ \\
\hline \multirow[t]{2}{*}{$S I Z E$} & $?$ & 0.0014 & -0.0277 & -0.0279 & $0.2431 * * *$ & $-0.3141 * * *$ & 0.0239 & 0.0175 \\
\hline & & (0.09) & $(-0.85)$ & $(-1.04)$ & $(5.60)$ & $(-5.75)$ & $(0.67)$ & $(0.46)$ \\
\hline \multirow[t]{2}{*}{$R O A$} & $?$ & -0.0781 & -0.0521 & -0.0108 & -0.3721 & 0.0561 & 0.1651 & $-0.1564 * * *$ \\
\hline & & $(-1.52)$ & $(-0.44)$ & $(-0.17)$ & $(-0.93)$ & $(0.61)$ & $(1.02)$ & $(-2.70)$ \\
\hline \multirow[t]{2}{*}{$M T B$} & $?$ & 0.0117 & -0.0231 & -0.0469 & -0.0962 & 0.0512 & 0.0790 & 0.0823 \\
\hline & & $(0.42)$ & $(-0.26)$ & $(-1.18)$ & $(-0.81)$ & $(0.43)$ & $(1.12)$ & $(1.58)$ \\
\hline Fixed Event Industry & & Yes & Yes & Yes & Yes & Yes & Yes & Yes \\
\hline Fixed Event Country & & Yes & Yes & Yes & Yes & Yes & Yes & Yes \\
\hline Constant & & Yes & Yes & Yes & Yes & Yes & Yes & Yes \\
\hline $\mathrm{N}$ & & 4,462 & 348 & 1,42 & 152 & 335 & 1,005 & 1,202 \\
\hline Adj. R-squared & & 0.4778 & 0.1692 & 0.6589 & 0.6439 & 0.1387 & 0.1054 & 0.0433 \\
\hline
\end{tabular}

Table 5 shows that TRANS denotes negative estimated parameters for all subsamples, being significant for Overall $\left(-0.0013^{* *}\right)$, Southern Europe $\left(-0.0026^{* * *}\right)$, and mainly for North America $\left(-0.0041^{* * *}\right)$, and last, for the excerpt of firms studied by Barth et al. (2013). This evidence might be understood to take into consideration at least two factors. First, the United States has the largest capital market in the world. According to the World Federation of Exchanges, in 2010 the New York Securities Exchange (NYSE) negotiated over US \$12.4 trillion in assets. Moreover, there is a traditional association between financial statements and investors' information concerns in the USA (e.g., Ball and Brown, 1968; Beaver, 1968).

Thus, we can mention that our results are aligned with these previous studies indicating that increases in earnings transparency reduce the cost of capital due to the decrease in information asymmetry (Healy and Palepu, 2001; Lambert et al., 2007; Johstone, 2015).

The control variable $L E V$ also revealed a positive parameter for all occasions, being significant for the total sample $\left(0.0045^{*}\right)$, North America $\left(0.0086^{* *}\right)$, Eastern Europe $\left(0.0813^{* *}\right)$, and Western Europe $\left(0.0092^{* *}\right)$, whose explanations involve the cost of debt, i.e., more leveraged companies have a higher cost of capital (Lambert et al., 2007; Johnstone, 2015). There is no need to mention the other control variables SIZE, ROA and MTB; see the similarities in Table 3.

Northern Europe showed the lowest coefficient $\left(-0.001^{*}\right)$ but is equally negative and significant. Latin America, Eastern Europe, Southern Europe, and Western Europe also demonstrated negative and significant coefficients, $-0.005^{*},-0.021^{*},-0.026^{*}$, and $-0.010^{*}$ respectively.

Based on these results, and considering the overall coefficient, $-0.013^{* *}$, it is possible to corroborate Hypothesis (2), i.e., that earnings transparency is negatively associated with the cost of equity, and this relation is statistically significant. This statement indicates that earnings transparency is one accounting feature perceived by stock price analysts and shareholders, respectively reflected in the cost of equity. These findings are in line with previous findings provided by Francis et al. (2008), Bhattacharya et al. (2013), Barth et al. (2013, 2015) and Beigi et al. (2016). 
Such findings about the relationship between earnings transparency and Ke remain valid and are in line with previous studies.

In general, these results still indicate that an increase in earnings transparency is a potential deflator of the cost of equity. From this empirical finding, it is possible to understand that accounting procedures aiming to increase the quality and the value-relevance of financial statements are relevant to investors, as this group can incorporate these features in its valuation models and reflect it in their decision process.

Table 6. Robustness Test - Findings for Cost of Capital (KE) and Discretionary Accruals

\begin{tabular}{|c|c|c|c|c|c|c|c|c|}
\hline & & Overall & $\begin{array}{c}\text { Latin } \\
\text { America }\end{array}$ & $\begin{array}{c}\text { North } \\
\text { America }\end{array}$ & $\begin{array}{c}\text { Eastern } \\
\text { Europe }\end{array}$ & $\begin{array}{l}\text { Southern } \\
\text { Europe }\end{array}$ & $\begin{array}{l}\text { Western } \\
\text { Europe }\end{array}$ & $\begin{array}{l}\text { Northern } \\
\text { Europe }\end{array}$ \\
\hline VARIABLES & Prediction & $\mathrm{Ke}$ & $\mathrm{Ke}$ & $\mathrm{Ke}$ & $\mathrm{Ke}$ & $\mathrm{Ke}$ & $\mathrm{Ke}$ & $\mathrm{Ke}$ \\
\hline DAC & - & $\begin{array}{c}-0.0001 \\
(-0.72)\end{array}$ & $\begin{array}{c}-0.0001 \\
(-0.35)\end{array}$ & $\begin{array}{c}-0.0007 * \\
(-1.91)\end{array}$ & $\begin{array}{c}-0.0003 \\
(-0.42)\end{array}$ & $\begin{array}{c}-0.0006^{*} \\
(-1.67)\end{array}$ & $\begin{array}{c}0.0002 \\
(0.48)\end{array}$ & $\begin{array}{c}-0.0000 \\
(-0.05)\end{array}$ \\
\hline$L E V$ & $?$ & $\begin{array}{c}-0.0002 \\
(-0.27)\end{array}$ & $\begin{array}{c}0.0306 * * * \\
(2.85)\end{array}$ & $\begin{array}{c}0.0026 \\
(0.81)\end{array}$ & $\begin{array}{c}-0.0153 * * \\
(0.34)\end{array}$ & $\begin{array}{c}0.0020^{*} \\
(1.74)\end{array}$ & $\begin{array}{c}-0.0012 \\
(-0.93)\end{array}$ & $\begin{array}{c}-0.0000 \\
(-0.03)\end{array}$ \\
\hline SIZE & $?$ & $\begin{array}{c}0.0053 \\
(1.48)\end{array}$ & $\begin{array}{c}-0.3216^{* * *} \\
(-2.18)\end{array}$ & $\begin{array}{c}-0.0415 \\
(-0.53)\end{array}$ & $\begin{array}{c}-0.1584 \\
(-1.02)\end{array}$ & $\begin{array}{c}0.0032 \\
(0.18)\end{array}$ & $\begin{array}{c}0.0035 \\
(0.31)\end{array}$ & $\begin{array}{c}0.0033 \\
(0.52)\end{array}$ \\
\hline$R O A$ & $?$ & $\begin{array}{l}0.0113 \\
(1.40)\end{array}$ & $\begin{array}{c}0.0298 \\
(0.44)\end{array}$ & $\begin{array}{c}0.0003 \\
(0.01)\end{array}$ & $\begin{array}{c}-0.0400 \\
(-0.24)\end{array}$ & $\begin{array}{l}0.0215 \\
(0.90)\end{array}$ & $\begin{array}{c}0.0037 \\
(0.11)\end{array}$ & $\begin{array}{c}0.0075 \\
(0.70)\end{array}$ \\
\hline$M T B$ & $?$ & $\begin{array}{c}-0.1512 \\
(-2.51)\end{array}$ & $\begin{array}{l}0.0174 \\
(1.16)\end{array}$ & $\begin{array}{c}-0.0023 \\
(-1.20)\end{array}$ & $\begin{array}{l}-0.3961 \\
(-1.24)\end{array}$ & $\begin{array}{c}-0.1095 \\
(-1.02)\end{array}$ & $\begin{array}{l}-0.0287 \\
(-2.24)\end{array}$ & $\begin{array}{c}-0.0358 \\
(-2.06)\end{array}$ \\
\hline Fixed Event Industry & & Yes & Yes & Yes & Yes & Yes & Yes & Yes \\
\hline Fixed Event Country & & Yes & Yes & Yes & Yes & Yes & Yes & Yes \\
\hline Constant & & Yes & Yes & Yes & Yes & Yes & Yes & Yes \\
\hline $\begin{array}{l}\mathrm{N} \\
\text { Adj. R-squared }\end{array}$ & & $\begin{array}{c}4,608 \\
0.0099\end{array}$ & $\begin{array}{c}352 \\
0.2952\end{array}$ & $\begin{array}{c}1,429 \\
0.0246\end{array}$ & $\begin{array}{c}165 \\
0.0234\end{array}$ & $\begin{array}{c}390 \\
0.0384\end{array}$ & $\begin{array}{c}1,056 \\
0.0416\end{array}$ & $\begin{array}{c}1,216 \\
0.0054\end{array}$ \\
\hline
\end{tabular}

Table 6 shows that DAC applies only to North American $\left(-0.0007^{*}\right)$ and Southern European $\left(-0.0006^{*}\right)$ firms, i.e., DAC negatively and statistically affects the cost of capital (Ke) for North American and Southern European companies.

The control variables $L E V, S I Z E, R O A$, and $M T B$ denoted the same trend of results found in previous tables. All regressions incorporated industry, fixed event, country and constant.

\section{Conclusion}

This study examines whether earnings transparency affects the cost of debt $(\mathrm{Ki})$, with the same relevance that previous studies related to the cost of equity (e.g., Francis et al., 2008; Bhattacharya et al., 2013; Barth et al., 2013, 2015; Beigi et al., 2016). The earnings transparency measure used was the same one used by Barth $e t$ al. (2013, p. 221), called TRANS, and it is 'based on the explanatory power of the returns-earnings relation, i.e., the extent to which earnings and change in earnings covary contemporaneously with returns.'

The results found showed that earnings transparency did not affect the cost of debt, such as the cost of equity. While the variable TRANS was negatively and statistically significantly correlated with Ke, it showed only a negative association with $\mathrm{Ki}$, but without any significance.

Additionally, this finding corroborates the main idea advanced in previous studies (e.g., Demerjian, 2011; Ball et al., 2015), that investors and creditors have different interests related to accounting information, and for this reason perceive accounting information features, such as earnings transparency, differently. Furthermore, there are at least two perspectives to better understand these findings: (i) an accounting procedure that potentially provides an increase in earnings transparency, which is not essentially similarly perceived by creditors, such as investors, and thus does not affect lenders' judgment about the agreed interest rates in financial liabilities contracts; and (ii) perhaps creditors are unable to recognize and integrate the specifications of accounting information quality in their credit risk models.

We suggest conducting future studies aiming to evaluate the effects of other quality features of accounting information, such as comparability and timeliness, among others, in the context of creditors' and lenders' perspectives, aiming to verify the reaction of these financial resources' allocators to accounting numbers. 


\section{References}

Ball, R., \& Shivakumar, L. (2005). Earnings Quality in Uk Private Firms: Comparative Loss Recognition Timeliness. Journal of Accounting and Economics, 39(1), 83-128. https://doi.org/10.1016/j.jacceco.2004.04.001

Ball, R., Robin, A., \& Wu, J. (1999). Properties of Accounting Earnings under the Enforcement Institutions of East Asian Countries, and Implications for Acceptance of IAS. Working Paper, University of Rochester.

Barth, M. E., \& Schipper, K. (2008). Financial Reporting Transparency. Journal of Accounting, Auditing \& Finance, 23(2), 173-90. https://doi.org/10.1177/0148558X0802300203

Barth, M. E., Konchitchki, Y., \& Landsman, W. R. (2013). Cost of Capital and Earnings Transparency. Journal of Accounting and Economics, 55(2), 206-24. https://doi.org/10.1016/j.jacceco.2013.01.004

Barth, M. E., Landsman, W. R., Raval, V., \& Wang, S. (2015). Asymmetric Timeliness and the Resolution of Investor Disagreement and Uncertainty at Earnings Announcements. Working Paper no. 162, Rock Center for Corporate Governance at Stanford University.

Beigi, F., Hosseini, M., \& Qodsi, S. (2016). The Effect of the Earning Transparency on Cost of Capital Common Stock Based on the Fama-French and Momentum Factors. Procedia Economics and Finance, 36, 244-55. https://doi.org/10.1016/S2212-5671(16)30035-1

Bhattacharya, N., Desai, H., \& Venkataraman, K. (2013). Does Earnings Quality Affect Information Asymmetry? Evidence from Trading Costs. Contemporary Accounting Research, 30(2), 482-516. https://doi.org/10.1111/j.1911-3846.2012.01161.x

Bhattacharya, U., Daouk, H., \& Welker, M. (2003). The World Price of Earnings Opacity. EFA 2002 Berlin Meetings Presented Paper. https://doi.org/10.2308/accr.2003.78.3.641

Bodie, Z., Kane, A., \& Marcus, A. J. (2011). Investments, McGraw-Hill/Irwin, New York, NY.

Bushman, R., Chen, Q., Engel, E., \& Smith, A. (2004). Financial Accounting Information, Organizational Complexity and Corporate Governance Systems. Journal of Accounting and Economics, 37(2), 167-201. https://doi.org/10.1016/j.jacceco.2003.09.005

Calcagnini, G., Farabullini, F., \& Giombini, G. (2014). The Impact of Guarantees on Bank Loan Interest Rates. Applied Financial Economics, 24(6), 397-412. https://doi.org/10.1080/09603107.2014.881967

Demerjian, P. R. (2011). Accounting Standards and Debt Covenants: has the "Balance Sheet Approach" Led to a Decline in the Use of Balance Sheet Covenants? Journal of Accounting and Economics, 52(2), 178-202. https://doi.org/10.1016/j.jacceco.2011.08.004

Diamond, D. W., \& Verrecchia, R. E. (1991). Disclosure, Liquidity, and the Cost of Capital. The Journal of Finance, 46(4), 1325-59. https://doi.org/10.1111/j.1540-6261.1991.tb04620.x

Duffie, D., \& Singleton, K. J. (2012). Credit Risk: Pricing, Measurement, and Management. Princeton University Press, Oxford.

Easton, P. D., \& Harris, T. S. (1991). Earnings as an Explanatory Variable for Returns. Journal of Accounting Research, 29(1), 19-36. https://doi.org/10.2307/2491026

Francis, J., LaFond, R., Olsson, P., \& Schipper, K. (2005). The Market Pricing of Accruals Quality. Journal of Accounting and Economics, 39(2), 295-327. https://doi.org/10.1016/j.jacceco.2004.06.003

Francis, J., Nanda, D., \& Olsson, P. E. R. (2008). Voluntary Disclosure, Earnings Quality, and Cost of Capital. Journal of Accounting Research, 46(1), 53-99. https://doi.org/10.1111/j.1475-679X.2008.00267.x

Gerlach, S., \& Assenmacher, K. (2008). Financial Structure and the Impact of Monetary Policy on Asset Prices. CFS Working Paper No. 2008/30, Goethe University Frankfurt.

Healy, P. M., Hutton, A. P., \& Palepu, K. G. (1999). Stock Performance and Intermediation Changes Surrounding Sustained Increases in Disclosure. Contemporary Accounting Research, 16(3), 485-520. https://doi.org/10.1111/j.1911-3846.1999.tb00592.x

Hung, S., \& Qiao, Z. (2017). Shadows in the Sun: Crash Risk Behind Earnings Transparency. Journal of Banking and Finance, 83(C), 1-18. https://doi.org/10.1016/j.jbankfin.2017.06.007 
IASB (International Accounting Standards Board) (2013). Discussion Paper DP/2013/1. Retrieved from http://www.ifrs.org/current-projects/iasb-projects/conceptual-framework/discussion-paper-july-2013/docum ents/discussion-paper-conceptual-framework-july-2013.pdf.

Kim, O., \& Verrecchia, R. E. (1994). Market Liquidity and Volume Around Earnings Announcements. Journal of Accounting and Economics, 17(1), 41-67. https://doi.org/10.1016/0165-4101(94)90004-3

Kraus, A., \& Litzenberger, R. H. (1973). A State-Preference Model of Optimal Financial Leverage. The Journal of Finance, 28(4), 911-922. https://doi.org/10.1111/j.1540-6261.1973.tb01415.x

Kumari, P., \& Mishra, C. S. (2018). Value relevance of earnings and book value in India: significance of accounting reforms and intangible-intensity in an emerging market. International Journal of Accounting, Auditing and Performance Evaluation, 14(4), 364-387. https://doi.org/10.1504/IJAAPE.2018.095112

Lambert, R., Leuz, C., \& Verrecchia, R. E. (2007). Accounting Information, Disclosure, and the Cost of Capital. Journal of Accounting Research, 45(2), 385-420. https://doi.org/10.1111/j.1475-679X.2007.00238.x

Lang, M., Lins, K. V., \& Maffett, M. (2012). Transparency, Liquidity, and Valuation: International Evidence on When Transparency Matters Most. Journal of Accounting Research, 50(3), 729-74. https://doi.org/10.1111/j.1475-679X.2012.00442.x

Lee, H. W., \& Gentry, J. A. (1995). An Empirical Study of the Corporate Choice Among Common Stock, Convertible Bonds and Straight Debt: a Cash Flow Interpretation. The Quarterly Review of Economics and Finance, 35(4), 397-419. https://doi.org/10.1016/1062-9769(95)90042-X

Lu, X., \& White, H. (2014). Robustness Checks and Robustness Tests in Applied Economics. Journal of Econometrics, 178, 194-206. https://doi.org/10.1016/j.jeconom.2013.08.016

Mazumdar, S. C., \& Sengupta, P. (2005). Disclosure and the Loan Spread on Private Debt. Financial Analysts Journal, 61(3), 83-95. https://doi.org/10.2469/faj.v61.n3.2731

Modigliani, F., \& Miller, M. H. (1958). The Cost of Capital, Corporation Finance and the Theory of Investment. The American Economic Review, 48(3), 261-97.

Myers, S. C., \& Majluf, N. S. (1984). Corporate Financing and Investment Decisions When Firms have Information that Investors do not have. Journal of Financial Economics, 13(2), 187-221. https://doi.org/10.1016/0304-405X(84)90023-0

Penman, S. H. (2013). Financial Statement Analysis and Security Valuation. McGraw-Hill Education, New York, NY.

Sengupta, P. (1998). Corporate Disclosure Quality and the Cost of Debt. The Accounting Review, 73(4), 459-74.

Uyemura, D. G., \& Van Deventer, D. R. (1993). Financial Risk Management in Banking. Irwin, Chicago.

Vaughan, E. J., \& Vaughan, T. M. (2013). Fundamentals of Risk and Insurance. John Wiley \& Sons, Incorporated, Hoboken, $\mathrm{NJ}$.

\section{Copyrights}

Copyright for this article is retained by the author(s), with first publication rights granted to the journal.

This is an open-access article distributed under the terms and conditions of the Creative Commons Attribution license (http://creativecommons.org/licenses/by/4.0/). 